University of Nebraska - Lincoln

DigitalCommons@University of Nebraska - Lincoln

USDA National Wildlife Research Center - Staff Publications
U.S. Department of Agriculture: Animal and Plant Health Inspection Service

2010

\title{
Assessing Potential Risk to Alligators, Alligator mississippiensis, from Nutria Control with Zinc Phosphide Rodenticide Baits
}

\author{
Gary W. Witmer \\ USDA-APHIS-Wildlife Services, gary.w.witmer@usda.gov \\ John D. Eisemann \\ USDA/APHIS/WS National Wildlife Research Center, John.D.Eisemann@aphis.usda.gov \\ Thomas M. Primus \\ USDA/APHIS Wildlife Services \\ Jeanette R. O'Hare \\ USDA/APHIS Wildlife Services \\ Kelly R. Perry \\ USDA/APHIS Wildlife Services \\ See next page for additional authors
}

Follow this and additional works at: https://digitalcommons.unl.edu/icwdm_usdanwrc

Witmer, Gary W.; Eisemann, John D.; Primus, Thomas M.; O'Hare, Jeanette R.; Perry, Kelly R.; Elsey, Ruth M.; and Trosclair, Phillip L. III, "Assessing Potential Risk to Alligators, Alligator mississippiensis, from Nutria Control with Zinc Phosphide Rodenticide Baits" (2010). USDA National Wildlife Research Center Staff Publications. 1349.

https://digitalcommons.unl.edu/icwdm_usdanwrc/1349

This Article is brought to you for free and open access by the U.S. Department of Agriculture: Animal and Plant Health Inspection Service at DigitalCommons@University of Nebraska - Lincoln. It has been accepted for inclusion in USDA National Wildlife Research Center - Staff Publications by an authorized administrator of DigitalCommons@University of Nebraska - Lincoln. 


\section{Authors}

Gary W. Witmer, John D. Eisemann, Thomas M. Primus, Jeanette R. O’Hare, Kelly R. Perry, Ruth M. Elsey, and Phillip L. Trosclair III 


\title{
Assessing Potential Risk to Alligators, Alligator mississippiensis, from Nutria Control with Zinc Phosphide Rodenticide Baits
}

\author{
Gary W. Witmer · John D. Eisemann • \\ Thomas M. Primus • Jeanette R. O'Hare • \\ Kelly R. Perry • Ruth M. Elsey • Phillip L. Trosclair III
}

This article is a U.S. government work, and is not subject to copyright in the United States.

Received: 20 February 2009/Accepted: 6 April 2010/Published online: 30 April 2010

(C) US Government 2010

\begin{abstract}
Nutria, Myocastor coypus, populations must be reduced when they cause substantial wetland damage. Control can include the rodenticide zinc phosphide, but the potential impacts to American alligators, Alligator mississippiensis, must be assessed. The mean amount of zinc phosphide per nutria found in nutria carcasses was $50 \mathrm{mg}$. Risk assessment determined that a conservative estimate for maximum exposure would be $173 \mathrm{mg}$ zinc phosphide for a $28 \mathrm{~kg}$ alligator, or $6.2 \mathrm{mg} / \mathrm{kg}$. Probit analysis found an $\mathrm{LD}_{50}$ for alligators of $28 \mathrm{mg} / \mathrm{kg}$. Our studies suggest that the use of zinc phosphide to manage nutria populations would pose only a small risk to alligators.
\end{abstract}

Keywords Alligator $\cdot$ Nutria $\cdot$ Residues $\cdot$ Zinc phosphide

Nutria, Myocastor coypus, are large semi-aquatic rodents native to South America (Bounds et al. 2003). Nutria were first introduced to the United States for their fur, and some populations remain economically important to the fur

G. W. Witmer $(\bowtie) \cdot$ J. D. Eisemann · T. M. Primus ·

J. R. O'Hare

USDA/APHIS Wildlife Services, National Wildlife Research Center, 4101 LaPorte Avenue, Fort Collins, CO 80521-2154,

USA

e-mail: Gary.W.Witmer@aphis.usda.gov

\section{K. R. Perry}

USDA/APHIS Wildlife Services, National Wildlife Research Center, 9730-B Lathrop Industrial Drive, Olympia, WA 98512, USA

R. M. Elsey · P. L. Trosclair III

Louisiana Department of Wildlife and Fisheries, Rockefeller Wildlife Refuge, 5476 Grand Chenier Highway, Grand Chenier, LA 70643, USA industry. Accidental and intentional releases have permitted them to become established in wetlands across the United States (Carter and Leonard 2002). Burrowing and foraging by nutria often inflict severe damage and can be devastating to native marshland vegetation and certain crops (LeBlanc 1994). Management plans to reduce nutria impacts require reducing populations or where possible eliminating nutria from target sites by hunting and trapping. However, alternative tools, including toxicants, need to be assessed for possible use, especially where incentive payment programs do not exist or when hunter harvest does not reduce damage to acceptable levels. Zinc phosphide is the only toxicant currently registered for controlling nutria and has been used for many years (LeBlanc 1994). When zinc phosphide baits are consumed, phosphine gas is generated in the stomach and intestines which relatively quickly causes heart and respiratory failure (Timm 1994). The $\mathrm{LD}_{50}$ (lethal dose for $50 \%$ mortality of the exposed animals) for zinc phosphide in nutria has been variously reported as $15-20 \mathrm{mg} / \mathrm{kg}$ (Spencer 1957) and as $5.55 \mathrm{mg} /$ $\mathrm{kg}$ (Timm 1994).

The potential hazards to non-target animals from zinc phosphide can be primary (direct consumption of the rodenticide bait) or secondary (consumption of an animal that has previously consumed the rodenticide bait). Alligators (Alligator mississippiensis) are an important natural resource in Louisiana (Joanen et al. 1997). Because nutria are a prey item for alligators and other predatory animals of the coastal marshes, it is imperative that methods used to control nutria populations do not significantly impact other wetland resources such as predator populations. Alligators are carnivorous so it is highly unlikely that they would consume vegetable rodenticide baits placed for nutria; hence, no primary hazard is expected. However, because alligators consume nutria as part of their diet (Elsey et al. 
1992; McNease and Joanen 1977; Valentine et al. 1972), a secondary hazard may exist.

This study was conducted under the approved USDA/ APHIS Wildlife Services' National Wildlife Research Center (NWRC) Project: Development and assessment of methods and strategies to monitor and manage invasive mammalian vertebrate species with emphasis on rodents. The study protocol (QA-1204) was approved by the NWRC Animal Care and Use Committee. We conducted this study in three steps: (1) determination of the amounts of zinc phosphide in nutria that have succumbed to zinc phosphide bait, (2) completion of a risk assessment to determine the zinc phosphide exposure alligators are likely to experience from consuming poisoned nutria, and (3) determination of the sensitivity of alligators to zinc phosphide by dosing alligators with various amounts of zinc phosphide in two different seasons.

\section{Materials and Methods}

The chemical assays of zinc phosphide residue amounts in gastrointestinal (GI) tracts from nutria fed zinc phosphide bait was used to indicate the probable exposure amount an alligator feeding on poisoned nutria could obtain. Only the GI tract was used because phosphine gas does not accumulate in tissues, but is liberated as a gas from the carcass. As a rodenticide, zinc phosphide baits generally kill the rodent quickly (often within a few hours) after consumption, so that undigested bait often remains in the GI tract (Johnson and Fagerstone 1994).

Fifteen captive nutria were fed zinc phosphide-treated $(0.67 \%$ active ingredient) sweet potatoes in pens in Olympia, Washington. This is the recommended application rate on the only zinc phosphide rodenticide label for nutria: USDA/APHIS' Zinc Phosphide for Rodent Control (EPA Reg. No. 56228-6). The nutria had been fed untreated sweet potatoes for several weeks prior to this rodenticide trial, but they were not offered alternative food during the trial. Twelve of the 15 nutria $(80 \%)$ died within $24 \mathrm{~h}$ of being offered the treated potatoes. The carcasses of the 12 nutria that succumbed to the zinc phosphide-treated potatoes were frozen and shipped overnight to the NWRC Analytical Chemistry Project (ACP) in Fort Collins, CO.

The ACP determined the amount of zinc phosphide residue in the GI tract of each nutria, using Analytical Chemistry Method 132A: determination of zinc phosphide residues in the gastrointestinal tract of nutria. The method is based on the chemical reaction whereby zinc phosphide is hydrolyzed in a solution of sulfuric acid, phosphine gas is generated. The sample for chemical analysis is prepared by removing the partially frozen GI tract from the nutria, homogenizing it in a stainless steel cylinder with liquid nitrogen by manually smashing with a steel rod. The sample is then transferred to a labeled plastic storage bag and vacuum sealed until a portion of sample is analyzed. Ten grams of the sample is placed into a $1,000 \mathrm{~mL}$ Erlenmeyer flask and $40 \mathrm{~mL}$ of a $30 \%$ sulfuric acid solution is added before the flack is tightly capped with a rubber stopper. The flask is placed in a mechanical shaker and agitated for $60 \mathrm{~min}$ at low speed. The phosphine gas in the headspace of the flask is then sampled via a 22 gauge needle attached to a sampling line that is attached to the pneumatic controlled valve with a $10 \mu \mathrm{L}$ sample loop. The phosphine gas generated from the samples and standards is injected into the gas chromatograph equipped with a $30 \mathrm{~m}$ by $0.53 \mathrm{~mm}$ id, $0.25 \mu \mathrm{m}$ GS-Q Megabore column (J and W Scientific, Folsom, CA) and detected by a flame photometric detector. The phosphine peak area response is recorded for all samples and standards to quantify the amount of zinc phosphide in all the nutria GI tract samples (Mauldin et al. 1996).

An $\mathrm{LD}_{50}$ of zinc phosphide to alligators was not available at the start of this study and little was found in the published literature to predict their susceptibility. In fact, no published data was found on the acute oral toxicity of zinc phosphide to reptiles. Nonetheless, we needed to determine the potential for alligators to succumb to secondary poisoning after consuming nutria baited with zinc phosphide rodenticide baits.

A risk assessment was conducted to (1) determine the concentration of zinc phosphide to which alligators may be exposed through consumption of poisoned nutria during operational applications, and (2) estimate an appropriate range of doses to test the toxicity of zinc phosphide to alligators. The risk assessment approach that we used followed that of the US Environmental Protection Agency (Urban and Cook 1986). A conservative worst case scenario was evaluated by utilizing the lowest acute oral $\mathrm{LD}_{50}$ reported for any vertebrate species as a surrogate for zinc phosphide toxicity to alligators. The lowest $\mathrm{LD}_{50}$ of zinc phosphide to vertebrates is $2.9 \mathrm{mg} / \mathrm{kg}$ for roof rats (Rattus rattus; Timm 1994). The zinc phosphide residue levels we found in poisoned nutria carcasses provided an important basis for the risk assessment, although various other parameters had to be estimated.

In the fall of 2004 (November-December), sixty wildcaught alligators (41 males and 19 females), 113-188 cm in length and $3.1-18.9 \mathrm{~kg}$ in mass, were collected and maintained by the Louisiana Department of Wildlife and Fisheries (LDWF) at Rockefeller Wildlife Refuge facilities in Grand Chenier, Louisiana. When captured, each alligator had its mouth taped for the safety of both people and alligators before each was weighed, measured for length, and its sex determined. The animals were group-housed in outdoor cement pens containing about $10 \mathrm{~cm}$ of water; they were not fed during the trials. The wood covers of the pens 
were closed except when handling the alligators. Because of the expertise of the personnel working at the state wildlife refuge and refuge policy, all aspects of animal care, including facilities, daily care, handling, and the dosing of alligators were conducted by LDWF personnel. Alligators were allowed several weeks to acclimate to the facilities and the daily care regime prior to the start of the trial. Alligators were randomly assigned to treatment groups but an effort was made to stratify the groups by size classes and sexes.

Based on the results of the risk assessment calculations, we determined that 3.0 and $6.0 \mathrm{mg} / \mathrm{kg}$ were appropriate initial dosages of zinc phosphide to determine whether alligators consuming poisoned nutria were likely to suffer ill affects. The risk assessment led us to test alligator responses to zinc phosphide exposure dosages of $0,3,6$, $15,30,60,120$, and $240 \mathrm{mg} / \mathrm{kg}$. There were 8 alligators in each group with the exception of the $3 \mathrm{mg} / \mathrm{kg}$ group which only had 4 animals. Zinc Phosphide for Rodent Control (containing 63.2\% zinc phosphide, EPA Reg. No. 56228-6) was provided by USDA/APHIS Wildlife Services' Pocatello Supply Depot (Pocatello, ID) and used under the direction and pesticide applicator license of the USDA/ APHIS Wildlife Services program in Louisiana.

In the fall 2004, initial trials to administer the zinc phosphide by feeding alligators pieces of chicken containing gelatin capsules filled with appropriate dosages were unsuccessful. Usually the alligators would not swallow the chicken. An alternative oral gavage method was used whereby the capsules were pushed through a plastic tube inserted into an alligator's stomach. After gavage, alligators were returned to their pens. They were observed daily to note any mortalities. After 1 month, the study was ended and all remaining animals were euthanized.

In the summer of 2005 (August-September), the second dosing trial was conducted to determine if the initial results would be different if conducted under warm weather and warm water conditions. Forty-eight alligators were used in this trial: 21 males and 27 females, 95.3$190.5 \mathrm{~cm}$ in length and $2.9-24.7 \mathrm{~kg}$ in mass. The trial was conducted as described above with a few exceptions: (1) each group contained 7 rather than 8 alligators, (2) the 2 highest doses (120 and $240 \mathrm{mg} / \mathrm{kg}$ ) were dropped because of the $100 \%$ mortality of those dosages in the first trial, and (3) another dosage $(10 \mathrm{mg} / \mathrm{kg})$ was added because a large increase in mortality had occurred between the 6 and $15 \mathrm{mg} / \mathrm{kg}$ groups in the first trial. We used the Probit Procedure of SAS statistical software (SAS Institute 2003) to estimate the $\mathrm{LD}_{50}$ of zinc phosphide for alligators. This response model fits the dose versus response (in our case, mortality) variables to the best distribution (normal or logistic) function.

\section{Results and Discussion}

The mean percent recovery of zinc phosphide from all quality control samples assayed was $78.0 \%$ (range $=61.2$ $104 \%, n=9$ ). During method validation, the recoveries observed were $80.1 \%$ with a range of $61.2-107 \%(n=19)$ for the fortification levels of 40.22 and $8,000 \mu \mathrm{g} / \mathrm{g}$ zinc phosphide, which occurred with the recoveries observed during analysis of samples. The method limit of detection for zinc phosphide in nutria GI tracts was $2.1 \mu \mathrm{g} / \mathrm{g}$. The method percent recovery was matrix dependent, and the recovery efficiency increased with increasing zinc phosphide concentration. The total mass of zinc phosphide is calculated by multiplying the concentration determined in $\mu \mathrm{g} / \mathrm{g}$ times the mass of the GI tract and converting the micrograms $(\mu \mathrm{g})$ to milligrams $(\mathrm{mg})$. The mean amount of zinc phosphide per nutria found in the GI tracts was $50.1 \mathrm{mg}(\mathrm{SD}=53.2 ;$ range $=11.7-173 \mathrm{mg})$. The average weight of the nutria carcasses was $5.2 \mathrm{~kg}(\mathrm{SD}=0.7$; range $=3.9-6.0$ ). Therefore, the poisoned nutria contained, on average, $9.6 \mathrm{mg}$ of zinc phosphide per $\mathrm{kg}$ of body weight. The highest concentration of zinc phosphide residue detected in the GI tract of poisoned nutria was $311 \mathrm{mg} / \mathrm{kg}$. The mass of the GI tract (removed from the same animal) was $0.56 \mathrm{~kg}$, and the total body mass was $6.16 \mathrm{~kg}$. Therefore, a maximum of $173 \mathrm{mg}$ zinc phosphide would be present in a nutria GI tract.

The chemical analysis documented residue levels in nutria fed zinc phosphide baits to range from 12.9 to $173 \mathrm{mg}$ per animal with a mean value of $50.1 \mathrm{mg}$. The average mass of the 12 nutria carcasses analyzed was $5.2 \mathrm{~kg}$. At this concentration, a $200 \mathrm{~kg}$ alligator would have to consume 3.4 nutria and a $350 \mathrm{~kg}$ alligator would have to consume 5.9 nutria to acquire the surrogate toxic dose of $2.9 \mathrm{mg} / \mathrm{kg}$. Small alligators (under about $1.8 \mathrm{~m}$ in length) are unlikely to consume nutria (R. Elsey, unpublished data). However, we estimated that a $28 \mathrm{~kg}$ alligator (the approximate mass for a $1.8 \mathrm{~m}$ animal) could eat a whole nutria, but would be unlikely to eat more than one at a time. Therefore, a conservative estimate for maximum exposure would be $173 \mathrm{mg}$ zinc phosphide for a $28 \mathrm{~kg}$ alligator, or $6.2 \mathrm{mg} / \mathrm{kg}$. The zinc phosphide exposure to an alligator this size consuming a whole nutria with the mean zinc phosphide residue amount (50.1 mg) is about $2-3 \mathrm{mg} / \mathrm{kg}$.

A more conservative approach in the risk assessment is to correct the residue data by taking into account the percent recovery from the GI tract samples. Because the method percent recovery was matrix dependent and the recovery efficiency increased with increasing zinc phosphide concentration, it is appropriate to interpolate the percent recovery from the quality control samples. The sample residues may then be corrected using the interpolated percent recovery. The interpolated percent 
recovery of the highest measured residue of $311 \mathrm{mg} / \mathrm{kg} \mathrm{GI}$ tract (173 mg per animal) is $78 \%$. Applying this recovery to correct the measured residue concentration of $311 \mathrm{mg} /$ $\mathrm{kg}$ for the GI tract matrix, the corrected concentration would be $399 \mathrm{mg} / \mathrm{kg}$, which yields $221 \mathrm{mg}$ of zinc phosphide with a GI tract having a mass of $0.56 \mathrm{~kg}$. At $221 \mathrm{mg}$ of zinc phosphide consumed per nutria carcass eaten, a $200 \mathrm{~kg}$ alligator would need to consume 2.7 nutria and the $350 \mathrm{~kg}$ alligator would need to consume 4.6 nutria to acquire the surrogate toxic dose of $2.9 \mathrm{mg} / \mathrm{kg}$. The assessment concluded that if alligators were as sensitive to zinc phosphide as roof rats, a very conservative assumption, a large alligator would have to eat approximately 3-6 poisoned nutria to succumb to the toxicant. The alligator dosing study, reported below, later determined that alligators were not nearly as sensitive to zinc phosphide as roof rats, so many more nutria would have to be consumed before mortality would occur.

In the fall 2004 trial, no alligators died at the 0,3 , and $6 \mathrm{mg} / \mathrm{kg}$ dosages. Most alligators died at 15 and $30 \mathrm{mg} / \mathrm{kg}$ dosages, and all died at the highest dosages: 60, 120, and $240 \mathrm{mg} / \mathrm{kg}$ (Table 1). The summer 2005 trial results followed a similar pattern as the fall trial, with some small differences. No alligators died at the 0 and $3 \mathrm{mg} / \mathrm{kg}$ dosages, but one alligator died at the $6 \mathrm{mg} / \mathrm{kg}$ dosage (Table 1). Mortality increased with higher dosages, but never reached the levels of the fall trial (Table 1). We added a $10 \mathrm{mg} / \mathrm{kg}$ dosage in the summer trial to see if the $\mathrm{LD}_{50}$ might be lower than $15 \mathrm{mg} / \mathrm{kg}$; it was not as only 2 of $7(28.6 \%)$ alligators in that group died. Hence, once again, there was little mortality at dosages below the $15 \mathrm{mg} / \mathrm{kg}$ dosage which resulted in $57.1 \%$ mortality. We combined the alligator mortality data across both seasons for the Probit procedural determination of the $\mathrm{LD}_{50}$ for alligators. The model estimated the an $\mathrm{LD}_{50}$ of $28 \mathrm{mg} / \mathrm{kg}$. This is considerably higher than the conservative surrogate level (2.9 $\mathrm{mg} / \mathrm{kg}$ for roof rats) used in the risk assessment.

From our preliminary risk assessment, we estimated that the maximum exposure likely to occur from an alligator feeding on a poisoned nutria was $6 \mathrm{mg} / \mathrm{kg}$. The oral exposure trials suggested that this exposure would result in very few if any alligator mortalities. Across both seasons, only 1 of $15(6.7 \%)$ alligators died at this dose. We also found that the $\mathrm{LD}_{50}$ for alligators is at least $15 \mathrm{mg} / \mathrm{kg}$, but may be somewhat higher at $28 \mathrm{mg} / \mathrm{kg}$. Hence, it appears that alligators are somewhat less sensitive to zinc phosphide than the target rodent species, nutria.

There have been a few reviews of potential zinc phosphide hazards to non-target animals, but none of these specifically addressed alligators. These reported no secondary poisoning of gopher snakes fed zinc phosphidepoisoned mice (Pauli and Money 2000) or snapping turtles fed zinc phosphide-poisoned nutria (Johnson and Fagerstone 1994). The snakes often regurgitated the mice and then showed no further response. Coulson and Hernandez (1983) noted that it is often difficult to force-feed alligators as they will often regurgitate the food, however, we found no evidence of regurgitation in our alligator study. Cats and raptors have also been known to regurgitate food tainted with zinc phosphide (Johnson and Fagerstone 1994). Johnson and Fagerstone (1994) noted one unpublished study in which zinc phosphide-poisoned nutria carcasses were fed to alligators. In that study, dosages ranging from 41.7 to $100 \mathrm{mg} / \mathrm{kg}$ were not lethal to alligators, while higher test dosages (150-250 mg/kg) were lethal. They also noted that another unpublished study reported observing dogs, opossums, raccoons, turtles, and blue crabs feeding on zinc phosphide-poisoned nutria, apparently without ill effects.

It was not unexpected that alligators died upon direct exposure (stomach gavage) of higher doses of zinc phosphide. An unusual finding, however, was that it took a considerable length of time for the alligators to die from the exposure: the average days until death in the fall trial was 14.1 days ( $\mathrm{SD}=5.9$ days), and in the summer trial, 7.5 days $(\mathrm{SD}=2.9$ days). When birds or mammals are exposed to a lethal dose of zinc phosphide, most are dead within 1 day and virtually all die within 3 days (Timm 1994). It could be that the slower metabolism of alligators or some of the other unique biochemical and physiological characteristics of alligators (Coulson and Hernandez 1983; Seebacher et al. 2003) are responsible for this delayed effect. Perhaps because alligators are very inactive in cooler air and water temperatures and will fast for long

Table 1 Percent alligator mortality after oral gavage with zinc phosphide by dosage and by season, 2004-2005

\begin{tabular}{llllllllll}
\hline & \multicolumn{1}{l}{ Dosage $(\mathrm{mg} / \mathrm{kg})$} \\
\cline { 2 - 9 } & 0 & 3 & 6 & 10 & 15 & 30 & 60 & 120 & 240 \\
\hline Percent mortality, fall 2004 & 0 & 0 & 0 & N/A & $87.5(7 / 8)$ & $75(6 / 8)$ & $100(8 / 8)$ & $100(8 / 8)$ & $100(8 / 8)$ \\
Percent mortality, summer 2005 & 0 & 0 & $14.3(1 / 7)$ & $28.6(2 / 7)$ & $57.1(4 / 7)$ & $28.6(2 / 7)$ & $57.1(4 / 7)$ & N/A & N/A \\
Percent mortality, both seasons & 0 & 0 & $6.7(1 / 15)$ & $28.6(2 / 7)$ & $73.3(11 / 15)$ & $53.3(8 / 15)$ & $80.0(12 / 15)$ & $100(8 / 8)$ & $100(8 / 8)$ \\
\hline
\end{tabular}

N/A Not applicable; that dosage not used in that season

Numbers in parentheses are the number of mortalities over the group size 
periods in the fall and winter (Coulson and Hernandez 1983; Seebacher et al. 2003), the delayed effect of the zinc phosphide was greater in our fall trial than in the summer trial. Unlike our study results, the unpublished study noted by Johnson and Fagerstone (1994) reported that there were no adverse effects to alligators consuming $41.7-100 \mathrm{mg} / \mathrm{kg}$ zinc phosphide, but did not indicate if test alligators were monitored long enough to observe mortalities. In bird and mammal toxicant studies with acute toxicants, animals are rarely monitored longer than 7-10 days post-exposure because usually all are dead within that time frame if they are going to succumb to the toxicant.

There is an additional aspect to the assessment of the potential of a nutria control program using zinc phosphide bait to adversely affect alligators. Thus far, we have addressed the potential effect on alligators at a defined level of exposure. The other aspect to consider is the likelihood of an alligator consuming a poisoned nutria. This could be influenced by at least two factors: the area of the nutria baiting program and the time of year of the baiting program. The area is important because alligator food habits vary by marsh type. In freshwater marshes (more inland), the frequency of occurrence of nutria in alligator stomachs was $64 \%$; this dropped to $42 \%$ in intermediate salt-water marshes, and dropped even further $(23 \%)$ in more coastal, brackish marshes (McNease and Joanen 1977). Crustaceans and fish become more important in the alligator diet as one moves southward to the coast where the brackish marshes are located (Elsey et al. 1992).

Finally, as noted before, alligators are not very active in the late fall and winter months and feed very little during that period. Hence, they are less likely to encounter and feed on poisoned nutria if a baiting program were conducted during that period. Fall, winter, and very early spring are when rodent control programs using rodenticides would generally be conducted because less activelygrowing marsh vegetation is available as food for the nutria which forage year-round. Hence, this and other measures (LeBlanc 1994) could be incorporated into a nutria control program using zinc phosphide baits to minimize the risk to non-target animals. While all risk cannot be eliminated, the long-term benefits to ecosystems and native species by reducing or eliminating populations of introduced rodents should be a primary consideration (Howald et al. 2007). In conclusion, it appears from our studies that the use of zinc phosphide baits to manage nutria populations would pose virtually no risk or impacts to alligator populations. That risk could be further minimized by following certain practices such as where and when the bait is used.

Acknowledgments We acknowledge the support and assistance provided by the Louisiana Department of Wildlife and Fisheries. Dwight LeBlanc, Louisiana State Director of USDA/APHIS Wildlife
Services, provided invaluable assistance. Funding was provided by the US Fish and Wildlife Service and the Louisiana Department of Wildlife and Fisheries. Helpful reviews of an earlier draft were provided by Michael Fall, Susan Jojola, and Dale Nolte.

\section{References}

Bounds DL, Sherfy MF, Mollett TA (2003) Nutria. In: Feldhamer GA, Thompson BC, Chapman JA (eds) Wild mammals of North America: biology management and conservation. The Johns Hopkins University Press, Baltimore, pp 1119-1147

Carter J, Leonard BP (2002) A review of the literature on the worldwide distribution, spread of, and efforts to eradicate the coypu (Myocastor coypus). Wildl Soc Bull 30:162-175

Coulson RA, Hernandez T (1983) Alligator metabolism: studies on chemical reactions in vivo. Pergamon Press, New York

Elsey RM, McNease L, Joanen T, Kinler N (1992) Food habits of native wild and farm-released juvenile alligators. In: Proceedings of the annual conference of the southeastern association of fish and wildlife agencies 46:57-66

Howald G, Donlan C, Galvan J, Russell J, Parkes J, Samaniego A, Wand Y, Veitch D, Genovesi P, Pascal M, Saunders A, Tershy B (2007) Invasive rodent eradication on islands. Conserv Biol 21:1258-1268

Joanen T, McNease L, Elsey R, Staton M (1997) The commercial consumptive use of the American Alligator (Alligator mississippiensis) in Louisana: its effect on conservation. In: Freese $\mathrm{CH}$ (ed) Harvesting wild species-implications for biodiversity. The Johns Hopkins University Press, Baltimore, pp 465-506

Johnson GD, Fagerstone KA (1994) Primary and secondary hazards of zinc phosphide to non-target wildlife-a review of the literature. USDA National Wildlife Research Center Research Report 11-55-005, Fort Collins

LeBlanc D (1994) Nutria. In: Hygnstrom SE, Timm RM, Larson GE (eds) Prevention and control of wildlife damage. Cooperative Extension Service, University of Nebraska, Lincoln, pp B71B80

Mauldin R, Goldade D, Engeman R, Goodall M, Craver R, Johnston J (1996) Determination of zinc phosphide residues in the California ground squirrel by gas chromatography-flame photometric detection. J Agric Fd Chem 44:189-194

McNease L, Joanen T (1977) Alligator diets in relation to marsh salinity. In: Proceedings of the annual conference of the southeastern association of fish and wildlife agencies 31:36-40

Pauli BD, Money S (2000) Ecotoxicology of pesticides in reptiles. In: Sparling D, Linder G, Bishop C (eds) Ecotoxicology of amphibians and reptiles. Society of Environmental Toxicology and Chemistry, Pensacola, pp 269-324

SAS Institute (2003) SAS version 9.1. SAS Institute, Cary

Seebacher F, Guderley H, Elsey RM, Trosclair PL III (2003) Seasonal acclimatization of muscle metabolic enzymes in a reptile (Alligator mississippiensis). J Exper Biol 206:1193-1200

Spencer HJ (1957) Nutria investigations. USDA National Wildlife Research Center Report WRL-57, Fort Collins

Timm RM (1994) Description of active ingredients. In: Hygnstrom SE, Timm RM, Larson GE (eds) Prevention and control of wildlife damage. Cooperative Extension Service, University of Nebraska, Lincoln, pp G23-G62

Urban D, Cook N (1986) Standard evaluation procedure for ecological risk assessment. EPA/540/09-86/167. United States Environmental Protection Agency, Washington, DC

Valentine J, Walther J, McCartney K, Ivy L (1972) Alligator diets on the Sabine National Wildlife Refuge, Louisiana. J Wildl Manage 36:809-815 